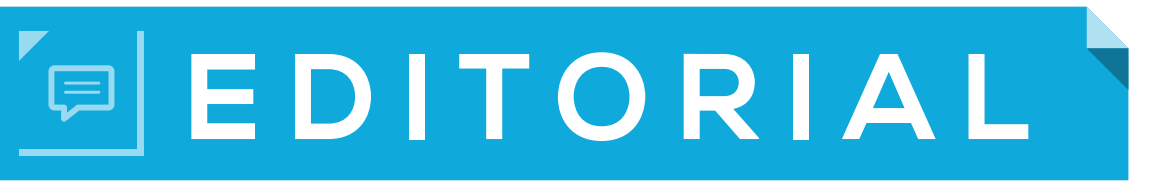

I N F O R M AT IO N

\title{
Let the Information Flow
}

\section{Franklin D. Roberts (froberts@ggc.edu), Assistant Dean of Library Services, Georgia Gwinnett College}

\begin{abstract}
1 bout twenty years ago I became the library director at a small state college in a far-northern state, known mostly for liberal social stances even among its conservative electorate. So I was taken aback when the head of computing recommended I install the same filtering software used in the public school system to protect students from getting into "mischief" online. College students are taking their first steps into adulthood, I explained when declining his offer, and they should get into mischief. They should be testing their boundaries, finding out the world is much different than the dinner conversations they grew up with surrounded by people whose main goal was protecting them.
\end{abstract}

I believed then, and still believe now, that my job as an information professional is to help people challenge the ideas they have been exposed to, to find out that other people have other ideas and other ways of living their lives that may even be diametrically opposed to what they have been exposed to as "normal." The only way students, or the patrons I used to serve as a public librarian, can know that there are other ways of looking at the world is to have as much unfettered access to information as I can give them. However, I also believe it is my role as an information professional to help equip these people with information literacy skills to locate the most accurate sources they can find in the middle of all of the "noise" out there. It is also to help inform students (and faculty and administrators and many others) that the First Amendment does allow for disagreement, even if it is messy.

As a newly reformed journal devoted to intellectual freedom and privacy, The Journal of Intellectual Freedom and Privacy has a key role for both the information professional and the layperson. It is a place we can spar about how we weigh freedom of access with freedom from offense-I want to read about how people justify having The Story of Little Black Sambo books alongside the updated Sam and the Tigers, or how we inform students that even though expression of contrary opinions might offend them, it is dangerous to simply say there can be no expression of contrary opinions. And regarding those contrary opinions, who decides which ones we get to explore and which ones we do not-who says something is "good," or something is "bad?" Should only prevailing opinions be considered, or should we consider not only what is orthodox, but also what is speculative? There are pluses to sharing a common culture, but there can also be strength in considering ideas that are not our own. I want to know how librarians are helping people who may be exploring new roles or ideas in the world-sexual orientation, emancipation from bad relationships, politically unpopular ideas-and making these ideas accessible to their patrons in what is perceived to be an increasingly insular political climate. How do we stand up to censors, left and right, who want to protect us from our own thoughts, not to mention the thoughts of "evil" Muslims or "racist" white male oppressors? The 
status quo should never be the status quo-if everything is always comfortable, how are we learning anything? I want to find out how my colleagues challenge the status quo simply by letting information flow.

Along with intellectual freedom, this journal focuses on privacy issues. We are living in a world that is rapidly becoming post-privacy - a world of Edward Snowden and Anonymous and many other groups or individuals who are making it their cause to expose everything that is private to the public. This leads to powerful revelations, like torture at Abu Ghraib or learning of the Taliban trying to silence Malala Yousafzai in Pakistan. But it also opens us up to embarrassing personal revelationsis there more than titillation driving revelations of who among our neigh-

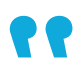
bors may have had an Ashley Madison account? How do we weigh the need for shedding light for the greater good with the public's seemingly insatiable need for dirt? As we nudge closer to Andy Warhol's "fifteen minutes of fame" prophecy, how much, ethically, do we really need to know about everyone else? And, in a post-privacy world, does revelation even matter? Is it just another means to viral-video fame? I want to read about how my colleagues are struggling with disclosure versus discretion, and I want to know if someone has found an answer, or at least a direction, to help balance those scales. And then there is regulatory disclosure-do terrorist acts like September 11 or the Bataclan concert hall attacks in Paris justify government having a back door to all encryption in the name of protecting us from bad guys? Does this back door open our lives to too much intrusion? Does safety only mean no one has privacy? Is that too high of a price for reassurance, or do the lives of our children matter more than who we are as individuals in the privacy of our own homes?

My hope is that others out there will take notice of this discussion and take part in it. It can be rational, passionate, dynamic, linear, or even blank verse, for all I care. The thoughts of others are important. My son taught me the quote, "None of us is as smart as all of us." All of us have voices and experiences-it is my hope we share both in these pages.

\section{Seeking Nominations and Applications for Editor}

The ALA Office for Intellectual Freedom seeks an Editor for the Journal of Intellectual Freedom and Privacy, a quarterly journal dedicated to both professional discourse and current news about intellectual freedom and privacy issues in libraries. The Editor will responsible for overseeing the journal's editorial content and working with its volunteer editorial board to shape the journal's direction. Responsibilities include soliciting and editing long-form submissions and book reviews, overseeing the peer-review process for submitted manuscripts that require review, and working with the news editor and OIF staff to identify and develop content for the journal's censorship news and court reports sections. The position is parttime and editors are compensated on a per-issue basis.

Candidates should ideally have an advanced degree in library and information sciences, law, or humanities and a strong background and interest in intellectual freedom, privacy, and professional ethics.

Interested candidates should send letters of inquiry to Deborah Caldwell-Stone, Office for Intellectual Freedom, American Library Association, 50 East Huron Street, Chicago, Illinois, 6061l. Correspondence may also be sent electronically to dstone@ala.org. 